\title{
Muscle pathology in juvenile dermatomyositis
}

Instituto de Infectologia Emílio Ribas, Seção de Anatomia Patológica - São Paulo, Brasil Laboratório de Patologia Molecular, Departamento de Patologia da Faculdade de Medicina da Universidade de São Paulo, Instituto Adolfo Lutz, Divisão de Patologia - São Paulo, Brazil

Objective: To study muscle biopsies, using histochemistry, on ten children with infantile dermatomyositis. Design: Series of ten patients (of whom eight patients had received treatment and two had not) were submitted to muscle biopsy in order to diagnose possible inflammatory myopathy or to detect recurrences. Place of development of the study: Public Health Service of São Paulo State. Participants: children with clinical features of inflammatory myopathy. Intervention: biopsies were performed on the vastus lateralis using local anesthetic. Histochemistry was performed according to standardized methods. Results: Architectural changes of the muscle fibers, necrosis of variable intensity and accentuated evidence of regeneration were observed in patients who had not received treatment ( 2 cases) and in one case where muscular weakness persisted in spite of corticosteroid therapy. Necrosis and regeneration were minimal or absent in cases treated for one year or more (4 cases). In 3 cases with clinical and laboratorial recurrences, muscle necrosis and architectural changes were detected. Conclusions: It was concluded that muscle biopsy could aid in diagnosing infantile dermatomyositis as well as in detecting recurrences even in cases without clinical activity of the disease.

UNITERMS: Juvenile dermatomyositis. Polymyositis. Muscle diseases. Histochemistry.

\section{INTRODUCTION}

$\mathbf{J}$ uvenile dermatomyositis is a rare disease with the greatest incidence between five and fourteen years of age'. It is a systemic disorder of unknown etiology, characterized by necrosis and regeneration of muscle fibers, with inflammation of muscle, skin and other tissues.

Systemic manifestations such as fever, lethargy and general discomfort may be the first symptoms of the illness,

\author{
Andress for correspondence: \\ Edenilson Eduardo Calore \\ Instituto de Infectologia Emílio Ribas - Seção de Anatomia \\ Patológica \\ Av. Dr. Arnaldo, 165 - Pacaembu \\ São Paulo/SP - Brasil - CEP 01246-900
}

with minimal muscle weakness. Cutaneous lesions are frequent and they appear at the onset or during the course of the disease. It can be difficult to recognize these lesions in black patients ${ }^{2}$.

It differs from adult polymyositis and dermatomyositis in some aspects. Firstly, vasculitis of small vessels is frequent, leading to ulcerations of the skin. Some patients can present calcinosis ${ }^{3}$ and the gastrointestinal tract, kidney and myocardium can be involved $d^{4,5.6}$. Moreover, juvenile dermatomyositis is always idiopathic, whereas inflammatory muscle disorders in adults can be part of a paraneoplastic syndrome?

Diagnosis is based on clinical criteria, elevation of serum muscle enzymes and compatible electromyography. The histological muscle features of the disease (inflammation, necrosis and regeneration of muscle fibers and perifascicular atrophy) are characteristic ${ }^{8}$. Its evolution is quite variable and depends partially on the type of treatment. 
This disorder may be classified according to its evolution as the acute monocyclic form, acute polycyclic form or continuous form ${ }^{9.10}$, respectively if the remission is complete, partial with recurrence, or if the disease is persistent in spite of corticosteroid therapy. This classification does not include the response to immunosuppressives such as ciclophosphamide, useful in some cases of dermatomyositis.

In the present work, we describe the histological and histochemical findings of skeletal muscle biopsy in 10 patients with juvenile dermatomyositis. We try to correlate these findings with the clinical response to the treatment and the clinical recurrence.

\section{MATERIAL AND METHODS}

Ten cases of juvenile dermatomyositis ( 2 boys and 8 girls, aged from $3 \frac{1}{2}$ to 14 years) were submitted to muscle biopsy. Dermatomyositis was diagnosed based on clinical criteria: cutaneous erithema or heliotrope associated to proximal muscle weakness of variable intensity. In one of the cases (case number 10) cutaneous lesions were not observed. However, inflammatory myopathy associated with perifascicular atrophy, which is characteristic in dermatomyositis, was observed by muscle biopsy.

The biopsy was performed on the vastus lateralis. The samples were frozen in $\mathrm{n}$-hexane previously cooled in liquid nitrogen and the sections were cut in a cryostat. Histological and histochemical techniques were performed according to Dubowitz, $1985^{\prime \prime}$.

Patients were subdivided into 3 groups (Table 1):

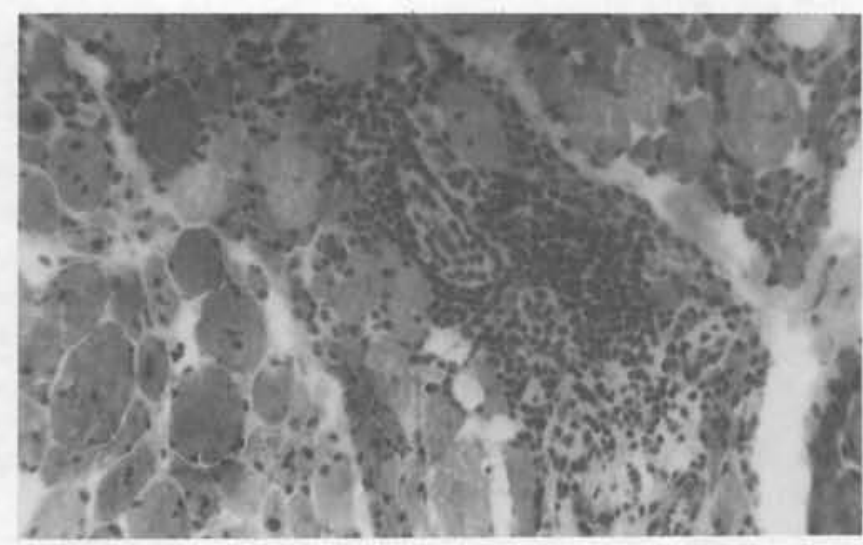

Figure 1 - Mononuclear invasion of necrotic muscle cells. Hematoxylin-Eosin stain (X400).
Group I: cases that had not received treatment (cases 1 and 2) or with persistence of the muscular weakness in spite of corticosteroid therapy (case 3, treated for 10 months);

Group II: cases that were treated for more than one year and with good clinical response (cases 4, 5, 6, 7);

Group III: cases that were treated and presented good clinical response, but with clinical or laboratorial recurrence (increase in muscle serum enzymes) at the time of the biopsy (cases 8,9 and 10).

The results of the histochemical study were graded (for each histochemical reaction) at three levels: $(+)$ rare occurrence of positive fibers; $(++)$ moderate number of positive fibers; $(+++)$ great number of positive fibers.

\section{RESULTS}

Group I: The mononuclear cellular response was moderate or intense. It invaded some muscle cells (Fig 1). The acid phosphatase reaction showed variable grades of necrosis, and the alkaline phosphatase reaction displayed moderate to intense features of regeneration. The oxidative enzymes, particularly the nicotinamide-adeninedinucleotide tetrazolium reductase (NADH-TR) reaction, showed marked architectural changes in muscle fibers, such as whorled, moth-eaten and target fibers (Fig. 2). Focal vasculitis was observed in case 3 .

Group II: mild necrosis and regeneration were seen with the acid and alkaline phosphatase reactions. The intermyofibrillar network of muscle fibers presented discrete changes with the NADH-TR reaction.

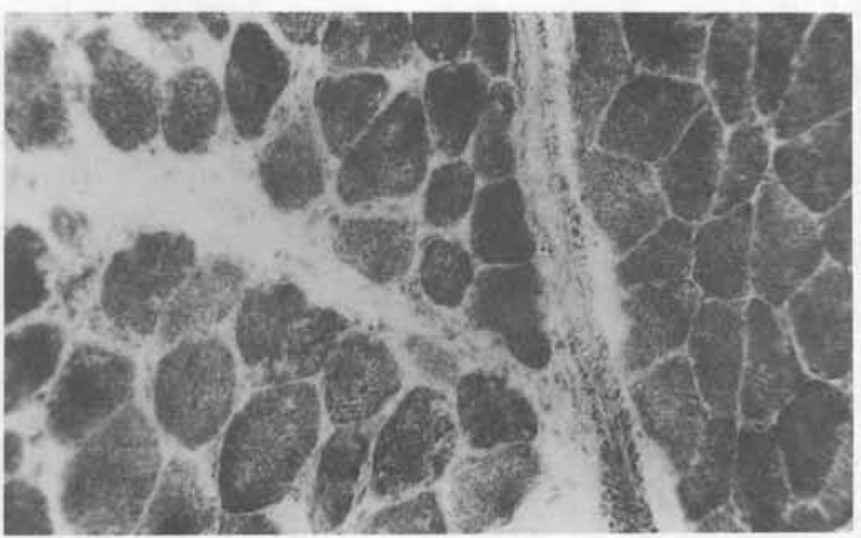

Figure 2 - Architectural changes in muscle fibers observed by the $\mathrm{NADH}-\mathrm{TR}$ reaction $(\mathrm{X} 400)$. 
Table 1

Clinical and histopathological data.

\begin{tabular}{|c|c|c|c|c|c|c|c|c|c|c|c|}
\hline Group & $\begin{array}{l}\text { Case } \\
\text { Number }\end{array}$ & $\begin{array}{l}\text { Age/ } \\
\text { Sex }\end{array}$ & $\begin{array}{l}\text { Time of disease/ } \\
\text { Time of treatment }\end{array}$ & Evolution & $\begin{array}{l}\text { Necrosis } \\
\text { (acid phosph) }\end{array}$ & Vasculitis & Infarct & $\begin{array}{l}\text { Regeneration } \\
\text { (alkaline phosph) }\end{array}$ & $\begin{array}{l}\text { Central } \\
\text { nuclei } \\
\% \text { fibres }\end{array}$ & $\begin{array}{l}\text { Architectural } \\
\text { Changes }\end{array}$ & Atrophy \\
\hline \multirow{3}{*}{1} & 1 & $\begin{array}{c}31 / 2 y \\
F\end{array}$ & not treated & $\begin{array}{l}\text { Proximal weakness } \\
\text { Enzymes elevated }\end{array}$ & ++ & - & - & +t+ & $20 \%$ & +++ & 一 \\
\hline & 2 & $\begin{array}{c}12 y \\
F\end{array}$ & not treated & $\begin{array}{l}\text { Proximal weakness } \\
\text { Contractures }\end{array}$ & $\stackrel{+}{+}$ & - & - & ++ & $10 \%$ & H+ & not selective \\
\hline & 3 & $\begin{array}{c}10 y \\
M\end{array}$ & $\begin{array}{c}11 / 2 y \\
10 \mathrm{~m} \text { treate }\end{array}$ & $\begin{array}{l}\text { Intense proximal } \\
\text { weakness }\end{array}$ & n++ & focal & - & n++ & $20 \%$ & + & fascicular \\
\hline \multirow{4}{*}{ II } & 4 & $\begin{array}{c}11 y \\
M\end{array}$ & $\begin{array}{l}2 y \text { disease/ } \\
2 y \text { treated }\end{array}$ & Good response & - & - & - & + & $30 \%$ & + & not selective \\
\hline & 5 & $\begin{array}{l}8 y \\
F\end{array}$ & $\begin{array}{l}2 \text { y disease/ } \\
2 \text { ytreated }\end{array}$ & Good response & + & - & - & + & $10 \%$ & + & not selective \\
\hline & 6 & $\begin{array}{c}11 y \\
F\end{array}$ & $\begin{array}{l}5 \mathrm{y} \text { disease/ } \\
2 \mathrm{y} / 2 \mathrm{y} \text { treated }\end{array}$ & $\begin{array}{l}\text { Clinical } \\
\text { improvement }\end{array}$ & - & - & - & + & $50 \%$ & + & not selective \\
\hline & 7 & $\begin{array}{l}9 y \\
F\end{array}$ & $\begin{array}{c}4 \text { y disease/ } \\
2 \text { first years } \\
\text { treated }\end{array}$ & $\begin{array}{c}\text { Clinical } \\
\text { improvement }\end{array}$ & $\begin{array}{c}+ \\
\text { (focal peri- } \\
\text { fascicular) }\end{array}$ & - & - & + & $20 \%$ & + & perifascicular \\
\hline \multirow{3}{*}{111} & 8 & $\begin{array}{c}7 y \\
F\end{array}$ & $\begin{array}{l}2 \text { y disease/ } \\
2 y \text { treated }\end{array}$ & Heliotrope & ++ & +++ & +++ & + & $10 \%$ & + & peritascicular \\
\hline & 9 & $\begin{array}{c}14 y \\
F\end{array}$ & $\begin{array}{l}2 y \text { disease/ } \\
2 y \text { treated }\end{array}$ & Elevated enzymes & +t+ & focal & - & + & $70 \%$ & ++ & not selective \\
\hline & 10 & $\begin{array}{c}14 y \\
F\end{array}$ & $\begin{array}{l}2 y \text { disease } \\
2 y \text { treated }\end{array}$ & $\begin{array}{l}\text { Intense weakness } \\
\text { Respiratory failure }\end{array}$ & n++ & n++ & - & n++ & $20 \%$ & ++ & $\begin{array}{l}\text { predominantly } \\
\text { perifascicular } \\
\end{array}$ \\
\hline
\end{tabular}

Group III: Moderate to intense degrees of necrosis were seen, as well as a moderate grade of regeneration. One case showed large regions of muscular infarct. Changes in the intermyofibrillar network were of moderate intensity. Vasculitis was observed in the three cases (Fig. 3).

Exclusively perifascicular atrophy was observed in a minority of cases (Fig. 4). However widespread muscle fiber atrophy (including perifascicular atrophy) was seen in 8 out of the 10 cases.

The results are summarized in Table I.

\section{DISCUSSION}

The histopathological features of skeletal muscle in juvenile dermatomyositis are essentially the same as those seen in adult dermatomyositis. These features include: inflammation with muscle fiber necrosis, vasculitis, muscular infarcts and perifascicular atrophy ${ }^{12}$.

The degree of inflammation is variable. In some cases it is scarce, being more intense in the perimysium and less intense in the endomysium. The inflammatory process comprises high percentages of B lymphocytes and T suppressor lymphocytes ${ }^{13}$. The intensity of the muscle fiber necrosis is variable and the necrotic fibers are frequently filled with macrophages. Around the vessels the inflammatory process may be exuberant and true vasculitis may be seen, possibly with fibrinoid necrosis of the small vessels.

Studies of the microvasculature of skeletal muscle of patients with dermatomyositis showed prominent capillary damage and capillary depletion that were not seen in other inflammatory myopathies, such as polymyositis ${ }^{14}$. Areas of infarcts due to vasculitis may also possibly be seen. 


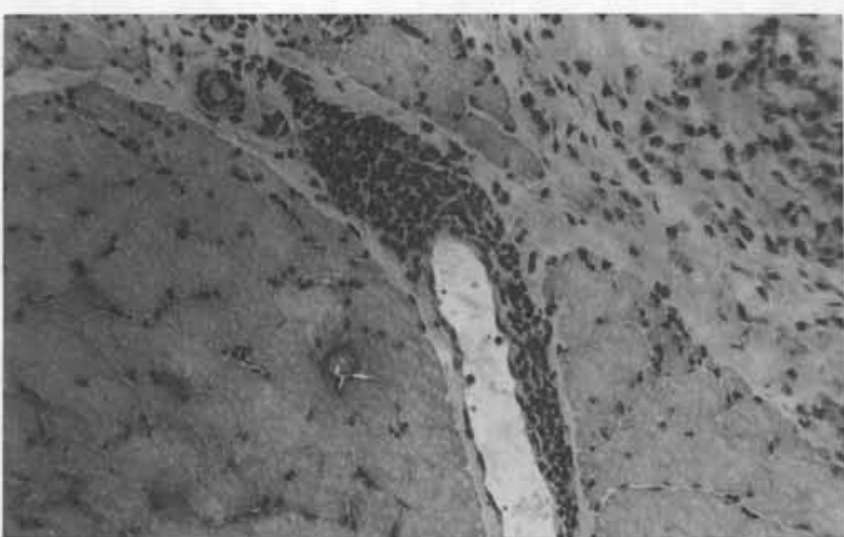

Figure 3 - Vasculitis of a small vessel. The wall is infiltrated by mononuclear cells. Hematoxylin-Eosin stain (X400).

Perifascicular atrophy is a distinct, characteristic phenomenon of dermatomyositis, even if rash is absent, although it can occur in other conditions such as scleroderma $^{12}$.

In the present series of patients, the intensity of necrosis has a relationship to the activity of the disease: cases that had not received treatment and cases with recurrence had more necrosis than cases with a good clinical response. Vasculitis was observed in cases with clinical or laboratorial recurrence and in the case where muscular weakness persisted in spite of corticosteroid therapy. The clinical signs of the patients with recurrence were variable: one patient presented only heliotrope; another showed an increase in serum enzymes (without any evidence of muscular weakness) and a third patient presented intense muscular weakness and respiratory failure.

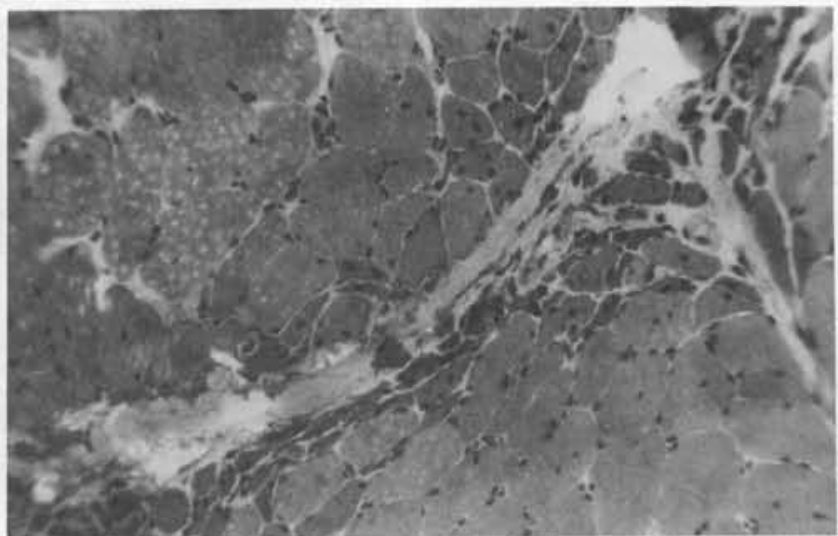

Figure 4 - Perifascicular atrophy. Hematoxylin-Eosin stain (X400).

Atrophy of muscle cells was a frequent finding (8/ 10 ), but was exclusively perifascicular in only two cases, without a clinical relationship to the evolution of the disease.

Changes in muscle fiber architecture by oxidative enzymes, were prominent in the two cases that had not received treatment, in the case without a good clinical response to treatment and in recurrent cases. These changes could be due to ischemia (caused by the vascular involvement) or due to the primary muscle inflammation.

In summary, we present the muscle pathology, using histochemistry, of 10 patients with infantile dermatomyositis. Although the number of cases is small (because it is a rare disease) the present data suggest that besides being useful for diagnosing infantile dermatomyositis, muscle biopsy may in addition detect recurrences even in some patients without obvious signs of activity of the disease.

\section{RESUMO}

Objetivo: estudar biópsias musculares através de histoquímica em dez crianças com dermatomiosite infantil. Desenho: Série de dez pacientes (oito dos quais receberam tratamento e dois que não o receberam) foram submetidos à biópsia para diagnóstico de possivel miopatia inflamatória, ou para a deteç̧ão de recorrências das mesmas. Local: Rede Pública de Saúde do Estado de S. Paulo. Participantes: crianças que supostamente apresentavam miopatia inflamatória. Intervenção: as biópsias musculares foram realizadas no músculo vasto lateral utilizando anestesia local. Foi realizada histoquímica de acordo com métodos padronizados. Resultados: Foram observadas alterações da arquitetura interna das fibras musculares, graus variados de necrose e sinais de regeneração nas biópsias de dois pacientes que não receberam tratamento e em um caso de persistência da fraqueza muscular apesar de corticoterapia. Nos casos com boa resposta ao tratamento, fibras em necrose ou regeneração foram observadas raramente. Em três casos com recorrência clínica ou laboratorial da doença foram observadas de forma abundante fibras musculares necróticas e outras fibras não necróticas com alterações da arquitetura interna. Conclusões: Conclui-se a partir do observado no presente trabalho que a biópsia muscular além de auxiliar no diagnóstico de dermatomiosite infantil, pode também auxiliar na detecção de recorrências, mesmo na ausência de sinais clínicos francos da doença. 


\section{REFERENCES}

1. Medsger TA, Dawson WN, Masi AT. The epidemiology of polymyositis. Am J Med 1970; 48: 715-23.

2. Bridges BF. The rashes of dermatomyositis in a black patient. Am J Med 1991; 91: 661-2.

3. Pachman LM. Juvenile dermatomyositis. Pediatr Clin North Am 1986; 33: 1097-1117.

4. Banker BQ. Dermatomyositis of childhood. J Neuropathol Exp Neurol 1975; 34: 46-75.

5. Ansell BM. Juvenile dermatomyositis. Ped Rheumatol 1991; 17: 931-43.

6. Cordone G, Buoncompagni A, Ciccone O et al. Dermatomiosite infantile. Aspetti clinici e prospettive terapeutiche. Minerva Pediatr 1991; 43: 621-30.

7. Callen JP. Malignancy in polymyositis/dermatomyositis. Clin Dermatol 1988; 6: 55-63.

8. Pachman LM. Juvenile dermatomyositis: a clinical overview. Pediatr Rev 1990; 12: 117-25.
9. Spencer C, Kornreich H, Bernstein B, King K, Singsen B, Hanson V. Three courses of juvenile dermatomyositis. Arthritis 1979, 22: 661-5.

10. Spencer C, Hanson V, Singsen B, Bernstein B, Kornreich H, King K. Course of treated juvenile dermatomyositis. J Pediatr 1984; 105: 399-408.

11. Dubowitz V. Muscle biopsy. A practical approach. London: Baillère Tindall, 1985: 19-40.

12. Engel AG, Hohlfeld R, Banker B. The polymyositis and dermatomyositis syndromes. In: Myology. AG Engel \& C Franzini. Armstrong Eds. 2nd Ed. New York: Mc Graw-Hill, 1994:1335-83.

13. Engel AG \& Arahata K. Mononuclear cells in myopathies: quantification of functionally distinct subsets, recognition of antigen-specific cell-mediated cytotoxicity in some diseases, and implications for the pathogenesis of the different inflammatory myopathies. Hum Pathol 1986; 17: 704-21.

14. Estruch R, Grau JM, Fernande-Solá J, Casademont J, Monforte R, Urbano-Márquez A. Microvascular changes in skeletal muscle in idiopathic inflammatory myopathy. Hum Pathol 1992, 23: 888-95. 